\title{
PENERAPAN LESSON STUDY UNTUK MENINGKATKAN KOMPETENSI GURU DI SMA MUHAMMADIYAH 1 DAN SMA MUHAMMADIYAH 4 KOTA BENGKULU
}

\author{
Oleh : \\ Kasmiruddin dan Endang Sulaeman \\ Universitas Muhammadiyah Bengkulu
}

\begin{abstract}
ABSTRAK
Perubahan budaya pembelajaran dari teacher centered learning ke student centered learning, menuntut guru untuk mampu memilih metode pengajaran yang mampu meningkatkan keaktifan siswa dalam belajar. Berdasarkan observasi di SMA Muhammadiytah 1 dan SMA Muhammadiyah 4 pada umumnya guru masih menggunakan metode konvensional. Kondisi ini menyebabkan siswa cenderung pasif dalam proses pembelajaran, akibatnya nilai rata-rata siswa pada beberapa bidang studi dibawah standar KKM Sekolah. Disamping itu pihak sekolah kurang merangsang guru untuk melakukan inovasi dalam pembelajaran. Bentuk kegiatan yang akan dilaksanakan adalah workshop lesson study bagi guru-guru di sekolah mitra, Open lesson dilanjutkan dengan Refleksi dan workshop evaluasi pelaksanaan lesson study. Kegiatan IPTEKS bagi Masyarakat (IbM) yang telah dilaksanakan dapat meningkatkan wawasan dan pemahaman guru tentang pembelajaran berbasis lesson study. Kegiatan ini dapat merubah pola pembelajaran dari teacher centered learning ke student centered learning teacher. Dengan demikian terjadi peningkatan aktivitas siswa dan guru.
\end{abstract}

\section{PENDAHULUAN}

Berdasarkan hasil observasi di SMA Muhammadiyah 1 diperoleh data bahwa proses pembelajaran yang dilakukan oleh guru pada umumnya masih menggunakan metode konvensional, yang cenderung berpusat pada guru (teacher center learning). Akibatnya siswa cenderung pasif. Kreatifitas yang dilakukan guru untuk meningkatkan keaktifan siswa hampir tidak ada, ditambah lagi dengan fasilitas pembelajaran yang juga masih minim. Kondisi ini mengakibatkan nilai rata-rata pada beberapa bidang studi di bawah standar KKM sekolah yaitu secara klasikal $85 \%$ siswa mendapat nilai 70 . Guru sebagai tenaga pengajar yang profesional hendaknya memiliki kemampuan untuk menerapkan metode pengajaran yang mampu meningkatkan keaktifan siswa dalam belajar. Namun sebagian besar guru belum memiliki pengetahuan yang memadai untuk melaksanakan pembelajaran yang bisa meningkatkan keaktifan siswa.

Berangkat dari permasalahan diatas kami ingin mencoba mengubah budaya pembelajaran dari teacher centered learning ke student centered learning, ini penting untuk mengurangi ketergantungan siswa terhadap gurunya. Salah satu alternatif untuk menjawab permasalahan tersebut adalah dengan menerapkan pembelajaran berbasis lesson 
study. Menurut Lewis (2002) Lesson Study merupakan model peningkatan mutu pembelajaran melalui pengkajian pembelajaran secara kolaboratif dan berkelanjutan berlandaskan prinsip-prinsip kolegalitas dan mutual learning, untuk membangun learning community. Podhorsky \& Moore (2006) menyatakan bahwa lesson study menyediakan suatu cara bagi guru untuk dapat memperbaiki pembelajaran secara sistematis. Selanjutnya Wang-Iverson (2002) dan Yoshida (2002) menyebutkan bahwa manfaat dari lesson study sebagai berikut:

1) Mengurangi keterasingan guru (dari komunitasnya)

2) Membantu guru untuk mengobservasi dan mengkritisi pembelajarannya

3) Memperdalam pemahaman guru tentang materi pelajaran, cakupan dan urutan materi dalam kurikulum

4) Membantu guru memfokuskan bantuannya pada seluruh aktivitas belajar siswa

5) Menciptakan terjadinya pertukaran pengetahuan tentang pemahaman berpikir dan belajar siswa

6) Meningkatkan kolaborasi pada sesama guru

Nurhadi, dkk (2010) melaporkan hasil lesson study yang telah dilaksanakan pada mata kuliah Geografi Regional Indonesia bahwa proses pembelajaran menjadi lebih baik dari segi materi, media, interaksi dosen dan mahasiswa serta peningkatan kemampuan mahasiswa pada bidang kognitif tingkat tinggi, afektif, psikomotor. Mahasiswa merasa mendapat bekal untuk kehidupannya kelak ketika sudah bekerja dan berkarya di tengah masyarakat.

Selanjutnya Djoko Santoso dan Sri Waluyanti (2010) melaporkan bahwa pembelajaran berbasis lesson study dapat meningkatkan penguasaan konsep dan psikomotorik mata kuliah Alat Ukur dan Pengukuran. Hasilnya diekspresikan dalam tes dan mengalami peningkatan, dari rerata 71.11 siklus I, 73.99 siklus II, dan 76.08 siklus III. Tanggapan mahasiswa terhadap implementasi pembelajaran tersebut berdasarkan angket tertutup diperoleh hasil $20 \%$ mahasiswa sangat setuju dan $80 \%$ setuju, tidak ada yang menyatakan tidak setuju dan sangat tidak setuju. Hasil penelitian Nursal dan Yuslim Fauziah (2013) menunjukkan bahwa penerapan lesson study dapat meningkatkan rata-rata hasil belajar mahasiswa dari 75.87 pada siklus 1 menjadi 87.80 pada siklus 2. Rata-rata nilai akhir pada pelaksanaan praktikum adalah 76.08. Selanjutnya Penelitian Primandari dkk (2013) menemukan bahwa pembelajaran menggunakan lesson study berpengaruh positif dan signifikan terhadap motivasi dan prestasi belajar siswa. Dari uraian diatas dapat disimpulkan bahwa penerapan lesson study merupakan solusi dari permasalahan yang dialami oleh dua mitra diatas.

\section{METODE PENGABDIAN}

\section{Bentuk Kegiatan}

a. Workshop Lesson Study bagi guru-guru di sekolah sasaran. 
Kegiatan workshop ini bertujuan untuk meningkatkan pemahaman guru secara komprehensif tentang pembelajaran berbasis lesson study mulai dari perencanaan (plan), pelaksanaan ( $d o$ ) dan refleksi (see).

b. Open Lesson dilanjutkan dengan Refleksi.

Kegiatan ini adalah penerapan lesson study oleh guru model pada bidang studi Biologi, Matematika, Geografi, Ekonomi dan Bahasa Indonesia.

c. Workshop Evaluasi Pelaksanaan Lesson Study.

Kegiatan ini bertujuan untuk mengevaluasi pelaksanaan lesson study oleh guru model yang sudah dilaksanakan.

\section{HASIL DAN PEMBAHASAN}

Persiapan yang dilakukan antara lain pengurusan perizinan dan koordinasi dengan kedua Sekolah mitra, yaitu SMA Muhammadiyah 1 dan SMA Muhammadiyah 4 Kota Bengkulu. Koordinasi dilakukan dengan Kapala Sekolah SMA Muhammadiyah 1 Bapak Pirwan Dahiwi, S.Pd., M.Pd.Si dan Kepala Sekolah SMA Muhammadiyah 4 Bapak Basirwan, S.Pd. Koordinasi dengan kedua Sekolah mitra tersebut dibicarakan hal-hal antara lain waktu pelaksanaan lokakarya lesson study, pelaksanaan open lesson di tiga bidang studi di masing-masing sekolah mitra. Hasil diskusi dengan Kepala Sekolah dan Wakil Kepala Sekolah bidang kurikulum disepakati bahwa pelaksanaan lokakarya lesson study dilaksanakan di Aula Kampus 3 Universitas Muhammadiyah Bengkulu, dengan peserta 15 orang guru dari SMA Muhammadiyah 1 dan 15 Orang guru dari SMA Muhammadiyah 4.

\section{Workshop Lesson Study bagi guru-guru di sekolah sasaran.}

Kegiatan workshop ini bertujuan untuk meningkatkan pemahaman guru secara komprehensif tentang pembelajaran berbasis lesson study mulai dari perencanaan (plan), pelaksanaan (do) dan refleksi (see). Kegiatan ini dilaksanakan pada tanggal 13 Mei 2015 di Aula Kampus 3 Universitas Muhammadiyah Bengkulu dengan peserta sebanyak 30 Orang guru. Acara lokakarya ini diawali dengan presentasi dari tim pelaksana dan dilanjutkan dengan diskusi/tanya jawab. Alat bantu yang digunakan disamping fotocopian makalah juga didukung dengan tampilan powerpoint menggunakan LCD projector. Ada tiga orang narasumber pada kegiatan ini yaitu : Dr. Irwandi, M.Pd, membawakan makalah dengan judul : “Lesson Study salah satu upaya Peningkatan Kompetensi Guru”, Dr. Risnanosanti, M.Pd, membwakan makalah dengan judul " Perangkat Pembelajaran 
Berbasis Lesson Study”dan Drs. Kasmiruddin, M.Si membawa makalah dengan judul “ Pelaporan Kegiatan Lesson Study".
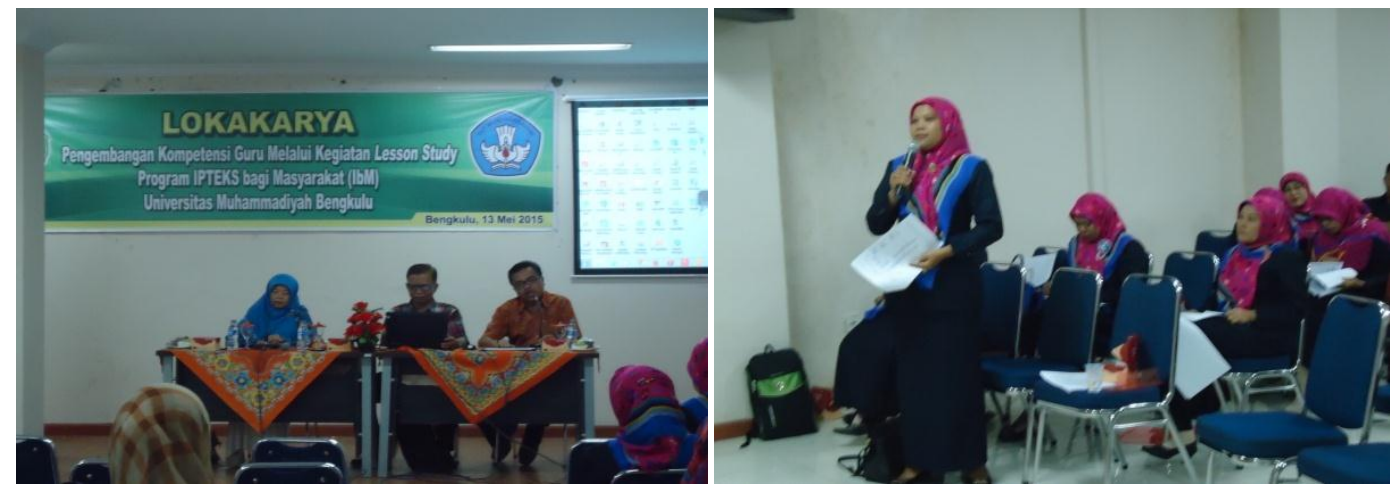

Gambar 1. Kegiatan Lokakarya Lesson Study

Dari hasil diskusi yang terjadi dalam lokakarya lesson study secara umum guruguru sudah memahami konsep dari lesson study. Guru-guru sudah memahami pembuatan perangkat pembelajaran berbasis lesson study, yang terdiri dari chapter design dan lesson design. Permasalahan yang diajukan oleh para guru dalam menerapkan lesson study adalah kesulitan untuk mencari observer (pengamat) kerena terbatasnya jumlah guru yang ada. Menurut narasumber pengamat boleh dari guru bidang studi yang lain, minimal 2 orang pengamat sudah cukup. Kendala lain menurut guru adalah masalah waktu untuk menerapkan lesson study. Menurut narasumber masalah waktu bisa diatasi dengan mengatur jadwal pelajaran pada awal semester sehingga guru-guru bisa mempersiapkan lesson study dengan baik.

\section{Kegiatan Open Lesson dan Refleksi.}

Kegiatan ini adalah penerapan lesson study oleh guru model pada berbagai bidang studi. Kegiatan Open lesson di SMA Muhammadiyah 1 dilaksanakan pada bidang studi Biologi, Bahasa Indonesia, Geografi dan SMA Muhammadiyah 4 dilaksanakan pada bidang studi matematika, biologi dan Ekonomi. Kegiatan Open lesson dilaksanakan diawali dengan :

\section{Penunjukkan Guru Model}

Penetapan Guru Model di tetapkan oleh Kepala Sekolah dengan Surat Tugas. Guru Model kedua sekolah mitra dapat dilihat pada tabel 1.

Tabel 1. Daftar Guru Model Sekolah Mitra

\begin{tabular}{cccc}
\hline No & Nama Sekolah & Guru Model & Bidang Studi \\
\hline 1. & SMA Muhammadiyah 1 & Elzas Priana, S.Pd & Biologi \\
& & Usri Maryanti, S.Pd & Geografi \\
& & Sartika Elfira, S.Pd & Bahasa Indonesia \\
2. & SMA Muhammadiyah 4 & Tri Handayani, S.Pd & Biologi \\
& & Rosi Rahmi, S.Pd & Matematika \\
\hline
\end{tabular}




\section{Kegiatan Open Lesson}

Pelaksanaan Open Lesson Pertama/Siklus I

\section{A. Tahap Perencanaan (Plan)}

Kegiatan plan diawali dari identifikasi masalah pada pembelajaran biologi, matematika, ekonomi, geografi, dan Bahasa Indonseia yang dilakukan oleh masingmasing guru model. Dalam kegiatan plan, hal-hal yang dilakukan adalah sebagai berikut.

a. Menganalisis materi ajar yang meliputi: kedalaman materi, kesesuaian dengan tuntutan kurikulum, dan tingkat kesulitan.

b. Menentukan strategi pembelajaran.

c. Guru model menyusun Chapter Design dan Lesson Design

d. Guru model mempresentasikan Chapter Desain dan Lesson Desain, Lembar kerja siswa, serta model pembelajaran di depan observer.

e. Observer memberikan masukan dan saran terkait dengan Chapter Desain dan lesson desain.

\section{B. Tahap Pelaksanaan (Do)}

Pada tahap pelaksanaan, masing-masing guru model melaksanakan proses pembelajaran sesuai dengan chapter design dan lesson design yang telah disusun. Jadwal kegiatan open lesson pada kedua sekolah mitra dapat dilihat pada Tabel 2 dan 3 .

Tabel 2. Kegiatan Open lesson di SMA Muhammadiyah 1 Kota Bengkulu

\begin{tabular}{|c|c|c|c|c|c|c|c|}
\hline \multirow[b]{2}{*}{ No } & \multirow{2}{*}{\multicolumn{2}{|c|}{ Guru Model }} & \multirow{2}{*}{$\begin{array}{c}\text { Bidang } \\
\text { Studi }\end{array}$} & \multicolumn{3}{|c|}{ Pelaksanaan } & \multirow[b]{2}{*}{ Kelas } \\
\hline & & & & $\begin{array}{c}\text { Open } \\
\text { Lesson I }\end{array}$ & $\begin{array}{c}\text { Open } \\
\text { Lesson II }\end{array}$ & $\begin{array}{c}\text { Open } \\
\text { lesson III }\end{array}$ & \\
\hline 1. & Elzas $\mathrm{P}$ & iana, S.Pd & Biologi & $\begin{array}{l}\text { Senin, } \\
5 \text { Oktober } \\
2015\end{array}$ & $\begin{array}{l}\text { Senin, } 12 \\
\text { Oktober } \\
2015\end{array}$ & $\begin{array}{l}\text { Senin, } 19 \\
\text { Oktober } \\
2015\end{array}$ & $\begin{array}{l}\text { XII IPA } \\
\text { Unggul }\end{array}$ \\
\hline 2. & $\begin{array}{l}\text { Usri } \\
\text { S.Pd }\end{array}$ & Maryanti, & Geografi & $\begin{array}{l}\text { Sabtu, } 10 \\
\text { Oktober } \\
2015\end{array}$ & $\begin{array}{l}\text { Sabtu, } 17 \\
\text { Oktober } \\
2015\end{array}$ & $\begin{array}{l}\text { Sabtu, } 24 \\
\text { Oktober } \\
2015\end{array}$ & $\begin{array}{l}\text { XII IPS } \\
\text { Unggul }\end{array}$ \\
\hline 3. & $\begin{array}{l}\text { Sartika } \\
\text { S.Pd }\end{array}$ & Elfira, & $\begin{array}{l}\text { Bahasa } \\
\text { Indonesia }\end{array}$ & $\begin{array}{l}\text { Rabu, } 7 \\
\text { Oktober } \\
2015\end{array}$ & $\begin{array}{l}\text { Rabu, } 21 \\
\text { Oktober } \\
2015\end{array}$ & $\begin{array}{l}\text { Rabu, } 28 \\
\text { Oktober } \\
2015\end{array}$ & XII IPS \\
\hline
\end{tabular}

Tabel 3. Kegiatan Open lesson di SMA Muhammadiyah 4 Kota Bengkulu

\begin{tabular}{llll}
\hline No & Guru Model & Bidang & Pelaksanaan
\end{tabular}




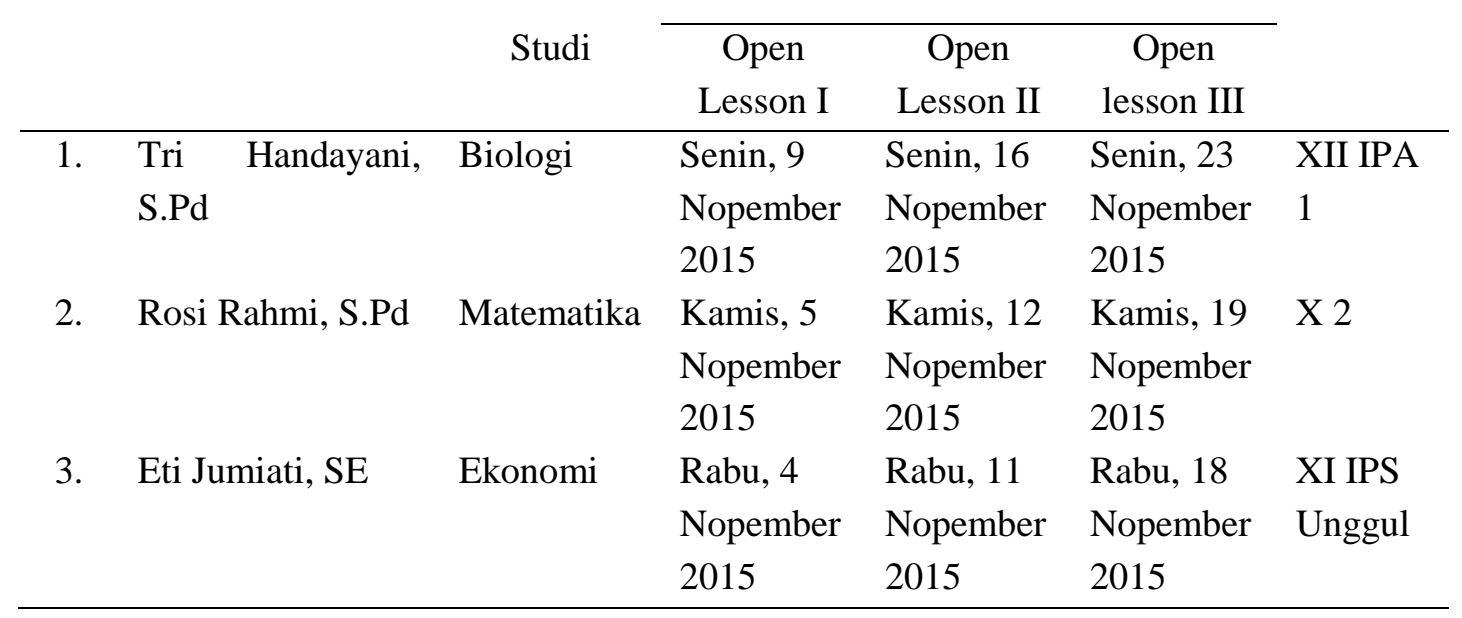

Proses pembelajaran yang dilaksanakan adalah:
a. Guru membuka pelajaran dengan mengucapkan salam
b. Guru mengabsen siswa
c. Guru mengkondisikan siswa untuk belajar
d. Memberikan motivasi dan apersepsi
e. Menyampaikan tujuan pembelajaran
f. Guru menyampaikan materi pembelajaran serta memberi contoh
g. Guru membentuk kelompok siswa kedalam beberapa kelompok
h. Guru membagikan LDS kepada siswa
i. Siswa melaksanakan diskusi dan mengerjakan LDS yang telah di sediakan.
j. Guru menganalisis dan mengevaluasi hasil diskusi
k. Guru memberikan umpan balik berupa pujian
1. Guru membimbing siswa untuk menarik kesimpulan
m. Guru memberikan tes.
C. Tahap Refleksi (See)

Setiap selesai open lesson dilaksanakan kegiatan refleksi untuk melihat hasil pelaksanaan proses pembelajaran yang telah dilakukan. Berdasarkan pengamatan yang dilakukan oleh observer pelaksanaan open lesson 1 menyatakan bahwa belum semua siswa terlibat aktif dalam berdiskusi, hanya sebagian kecil saja siswa yang terlibat aktif dalam berdiskusi. Hal ini disebabkan siswa belum terbiasa dengan kegiatan pembelajaran lesson study, siswa kelihatan agak terganggu dengan kehadiran observer, demikian juga dengan guru model belum terbiasa dengan kegiatan lesson study, akibatnya diskusi yang dilakukan oleh siswa menjadi monoton.

Pelaksanaan Open Lesson Kedua/Siklus II

\section{A. Tahap Perencanaan (Plan)}


Guru model menyusun Chapter design dan Lesson design dengan memilih strategi yang lebih menarik, dengan menampilkan media LCD Proyektor sehingga bisa menampilkan gambar-gambar yang menarik. LDS dibagikan untuk setiap anggota kelompok sehingga diharapkan semua anggota kelompok terlibat aktif berdiskusi dan mencari jawaban.

\section{B. Tahap pelaksanaan (Do)}

Guru model melaksanakan kegiatan pembelajaran sesuai dengan langkah-langkah yang telah disusun dalam chapter design dan lesson design. Penggunaan media LCD proyektor dalam pembelajaran membuat siswa lebih termotivasi.

\section{Tahap refleksi (See)}

Berdasarkan pengamatan yang dilakukan oleh observer menyatakan bahwa keaktifan siwa sudah semakin baik, hampir semua anggota kelompok terlibat aktif dalam berdiskusi. siswa sudah mulai terbiasa dengan kegiatan lesson study, demikian juga dengan guru model sudah terbiasa dengan kegiatan lesson study. Guru model sudah mampu membangkitkan keaktifan siswa dalam berdiskusi.

\section{Pelaksanaan Open Lesson Ketiga/Siklus III}

\section{A. Tahap Perencanaan (Plan)}

Hasil pelaksanaan pada open lesson kedua membangkitkan motivasi guru model untuk menerapkan strategi pembelajaran yang dapat membangkitkan keaktifan siswa. Masukan-masukan dari observer memperkaya lesson design dan chapter design yang disusun oleh guru model semakin baik.

\section{B. Tahap Pelaksanaan (Do)}

Guru model melaksanakan kegiatan pembelajaran sesuai dengan langkah-langkah yang telah disusun dalam chapter design dan lesson design. Penggunaan media LCD proyektor dalam pembelajaran membuat siswa lebih termotivasi. Pelaksanaan open lesson ketiga sudah semaikin baik, tanpa banyak penjelasan dari guru model siswa sudah bisa melaksanakan diskusi dengan baik. seluruh siswa sudah terlibat aktif dalam diskusi.

\section{Tahap Refleksi (See)}

Berdasarkan pengamatan dari observer terjadi peningkatan keaktifan siswa dalam proses pembelajaran pada open lesson ketiga. Ketika diskusi kelas kelompok siswa sangat antusias untuk tampil didepan kelas mempresentasikan hasil diskusi kelompoknya, dari sisni kelihatan bahwa siswa sangat termotivasi belajar dengan penerapan lesson study.

Setelah selasai kegiatan open lesson ketiga guru model melaporkan kepada tim bahwa siswa dikelasnya bertanya apakah pembelajaran selanjutnya nanti masih menerapkan kegiatan lesson study, kami berpesan kepada para guru model agar 
kegiatan lesson study ini diterapkan dalam setiap proses pembelajaran, kerena terbukti dapat meningkatkan keaktifan siswa dan guru dalam proses pembelajaran.

\section{KESIMPULAN}

Pelaksanaan program IPTEKS bagi Masyarakat (IbM) yang telah dilaksanakan dapat diambil kesimpulan:

1. Pelaksanaan kegiatan masih sesuai dengan yang diharapkan tanpa ada kendala yang cukup berarti.

2. Penerapan kegiatan lesson study dalam proses pembelajaran dapat meningkatkan keaktifan siswa dan guru.

3. Pemahaman guru tentang pembelajaran berbasis lesson study dan pembuatan perangkat pembelajaran berbasis lesson study sudah baik.

4. Penerapan lesson study dalam pembelajaran dapat merubah dari teacher centred learning menjadi student centred learning.

5. Guru sangat antusias menerapkan pembelajaran berbasis lesson study.

\section{DAFTAR PUSTAKA}

Direktorat Ketenagaan, 2008, Program Perluasan Lesson Study untuk Penguatan LPTK, Buku 3, Panduan Pelaksanaan, Lesson Study di LPTK, Direktorat Ketenagaan, Direktorat Jendral Pendidikan Tinggi, Departemen Pendidikan Nasional, Jakarta.

Djoko Santoso, Sri Waluyanti, 2010, Upaya Peningkatan Penguasan Konsep dan Psikomotorik Mata Kuliah Alat Ukur dan Pengukuran Berbasis Lesson Study Mahasiswa Jurdik Teknik Elektronika, Fakultas Teknik Universitas Negeri Yogyakarta.

Lewis, C., 2000, Lesson Study: The Core of Japanese Porfesional Development, Education Departemn of Mills College, Oakland, CA di http://lessonresearch.net.

Lewis, C., 2002, Lesson study: A handbook of teacher-led Instructional Change, Research for Better Schools, Philadelphia.

Nurhadi, Hadi, B.S., R.B. Gunardo, Suparmini, dan Nursa'ban, M., 2010, Laporan Pelaksanaan Lesson Study Mata Kuliah Geografi Regional Indonesia Di Jurusan Pendidikan Geografi Fise UNY, Jurusan Pendidikan Geografi Fakultas Ilmu Sosial Dan Ekonomi, Universitas Negeri Yogyakarta.

Nursal dan Yuslim Fauziah, 2013, Efektifitas Penerapan Lesson Study pada Pembelajaran Ekologi Tumbuhan di Program Studi Pendidikan Biologi FKIP Universitas Riau, Prosiding Semirata FMIPA Universitas Lampung.

Podhorsky, C. \& Moore, V., 2006, Issues in curriculum: Improving Instructional Practice through Lesson Study. Tersedia pada http://www.lessonstudy.net. 
Wang-Iverson, P., 2002, Why Lesson Study, http://www.rbs.org/lesson_study/confenrence/2002/paper/wang.shtml.

Yoshida, M., 2002, Developing Effective Use of the Blackboard through Lesson Study. http://www.rbs.org/lesson_study/confenrence/2002/paper/Yoshida_blacboard.shtm 1. 